Egyptian Journal of Aquatic Biology \& Fisheries

Zoology Department, Faculty of Science,

Ain Shams University, Cairo, Egypt.

ISSN $1110-6131$

Vol. 25(2): $803-817$ (2021)

www.ejabf.journals.ekb.eg

\title{
Assessment of Water Quality Using Heavy Metals Concentrations in Several Water Resources of Shatt Al-Arab and Tissues of the Nile Tilapia (Oreochromis niloticus) and the Shrimp (Metapenaeus affinis)
}

\author{
Mohammed A. Aldoghachi ${ }^{1 *}$ and Dhiaa E. Altamimi ${ }^{2}$
}

${ }^{1}$ Department of Marine Vertebrates, Marine Science Center, University of Basrah, Basrah, Iraq.

${ }^{2}$ Ecology unit, Al- Najibiya power plant, Basrah, Iraq.

* Author: mohammed.aldoghachi@uobasrah.edu.iq

ARTICLE INFO

Article History:

Received: Jan.22, 2021

Accepted: April 11, 2021

Online:April 30, 2021

\section{Keywords:}

Water quality,

Heavy Metals,

Tilapia,

Shrimp,

Shatt al-Arab

\section{ABSTRACT}

The present study was conducted to assess the water quality and bioaccumulation of heavy metals $(\mathrm{Cd}, \mathrm{Cu}, \mathrm{Pb}$, and $\mathrm{Zn})$ in tissues of the tilapia fish (Oreochromis niloticus) and shrimp (Metapenaeus affinis), which were caught from Shatt al-Arab river near Al- Najibiya power plant in Basrah, Iraq during Mar 2018 - Feb 2019. Aquatic samples consisted of raw water from the river, drainage channel water, and demi water from the inside electric power plant. 10 parameters including the electrical conductivity, total dissolved solids, total suspended solids, the concentration of hydrogen ions, calcium, magnesium, chloride, sulphate, phosphate, and temperature were examined. The results designated that a deterioration in the water quality of Shatt al-Arab was observed during the hot months, especially in the summer season of 2018. The conductivity rates were higher than the permissible limits compared to demi industrial water. Occurrence of heavy element concentrations of $\mathrm{Cd}$, and $\mathrm{Pb}$ were in slightly higher average level in water samples collected from river raw water $(0.62$ and $0.14 \mathrm{mg} / \mathrm{l})$ and drainage chanal water $(0.17$ and $0.15 \mathrm{mg} / \mathrm{l})$ respectively. The concentration average of the heavy metals in the investigated parts (muscle, gill, and liver) of the studied fish could be found with significant variation among examined tissues. The current study concluded that the metal concentrations in muscles of the tilapia fish and the edible parts from studied shrimps were within the limits permitted for human consumption.

\section{INTRODUCTION}

Shatt al-Arab is one of the most important inland rivers in Iraq, possessing a strategic geographical location in terms of the economic, political and military aspects as well as a source of drinking fresh water and fishing. Shatt al-Arab is an important water resource for Basra governorate, on which agricultural and industrial activities depend. Shatt alArab water quality is mainly affected by the quality of the water resource from the Tigris and Euphrates rivers (Abbas \& Hassan, 2018; Chabuk et al., 2020). The water quality and other river characteristics won the concern of many previous researchers. Since the study of water characteristics would allow to forecast the future quality, it has been 
widely surveyed being associated with different water uses. Recent researches focused on water resources distribution to maintain its quality and sustainability to preserve ecosystems, especially in river located at the lower reaches of the river basins such as Shatt al-Arab river (Al- Mahmood, 2009; Gatea, 2018; Al- Asadi et al., 2020). Shatt alArab River is an open environment and its water is affected by the discharges of the rivers and marshes in addition to the marine waters coming from the Arabian Gulf (AlTaei, 2014). It is noteworthy that, Shatt al-Arab is currently suffering from various activities such as the movement of boats and the leakage of industrial, agricultural and household waste that caused an increase in water pollution of this river (Al-Asadi et al., 2019).

Furtermore, pollutants that reach the aquatic environment are numerous and varied, including organic compounds such as hydrocarbons, and inorganic such as heavy metals. Pollutan has reached the aquatic environment through natural and artificial sources including all human activities (Singh et al., 2020). Remarkably, among the essential heavy metals for human body are: calcium $(\mathrm{Ca})$, ferrous $(\mathrm{Fe})$, cobalt $(\mathrm{Co})$, sodium $(\mathrm{Na})$ potassium $(\mathrm{K})$, copper $(\mathrm{Cu})$, magnesium $(\mathrm{Mg})$, molybdenum $(\mathrm{Mo})$, manganese $(\mathrm{Mn})$, and zinc (Zn) (Prasad, 2008; Couture \& Pyle, 2011; Marschner, 2012). Yet, any increase or decrease below certain concentrations would cause physiological damage in organs of organisms (Al-Asgah et al., 2015). Moreover, non-essential elements such as cadmium, if present, may cause both environmental and physiological damage that may lead to the death of the organism. Furthermore, heavy metals are primarily toxic to all organisms because of the similarity of its binding sites in cells as well as their reaction with and inhibition of sulfhydryl SH groups in the amino acid (Cysteine) of enzyme systems, like those involved in cellular energy production (Rana, 2006).

Toxic water pollutants cannot easily biodegrade, and thus cause major and serious health problems in industrial countries. Exposure cases are similar to diseases in terms of dividing them into acute and chronic types. Acute exposures are those that occur when exposed to high concentrations of toxic materials over short periods of time (Aldoghachi et al., 2016). Chronic exposures, which are more widespread in the general population, include exposure to low concentrations over long periods (Tana et al., 2020). Hence, fish can be used as a good biological indicator for pollution studies due to its responce to environmental changes, in addition to the easiness to obtain fish in large quantities and ideal sizes for analysis and long lifespan, beside their ability to accumulate minerals (Osorio et al., 2014). Particularly, the tilapia fish that belongs to the family of Ciclidae, known for its high tolerance and rapid growth (WWF, 2011). Therefore, the tilapian fish, Oreochromis niloticus, was selected in this study due to its availability for a long period in Shatt al-Arab river, tolerance of salinity variations in addition to its economic importance (AlKatrani et al., 2018). Metapenaeus affinis shrimp was also selected for spending part of its life for nursery in Shatt al-Arab and the marshes of southern Iraq for a 
period extended from May/June to January/February (Salman et al., 1990). Generally, this kind of shrimp has an economic importance too.

In the light of the growing crisis in water scarcity and the deterioration of its quality on a global and national levels, it is necessary to know the reason for the expected change in the water characteristics. Generally, urban areas near factories, especially electric power plants, are liable to be exposed to various pollutants. Therefore, the main aim of the current study was to assess the quality of Shatt al-Arab water, drainage channel and industrial water inside the power station using the parameters of: the $\mathrm{pH}$, conductivity, total dissolved solid (TDS), total suspended solids (TSS), calcium (Ca), magnesium $(\mathrm{Mg})$, aluminum $(\mathrm{Al})$, chloride $(\mathrm{Cl})$, sulfate $\left(\mathrm{SO}^{-2}\right)$, phosphate $\mathrm{PO}^{-2}$, ferrous $(\mathrm{Fe})$ and water temperature to determine the water suitability for various purposes. Moreover, the research was purposed to evaluate the heavy metals in the river water, tilapia fish; $O$. niloticus, and shrimp; M. affinis, which occur in this area in order to know the indicators of environmental pollution in Shatt al-Arab area near Al-Najibiya power station.

\section{MATERIALS AND METHODS}

\section{Study area}

Shatt al-Arab river near Najibiya power station/ Basrah was selected to be the study area. It is situated at $30.576189 \mathrm{~N} 47.764725 \mathrm{E}$ (Fig. 1). This area was chosen due to its important location in the activity of electric power production (General Company of Electrical Energy /South Region, 2019), as well as its affected area by the thrown industrial wastes of the aforementioned factory in Shatt al-Arab river.

Sampling started from Mar 2018 to Feb 2019. Aquatic samples were raw water from river (RW), Drainage chanal water (ChW) and demi water (DW) inside an electric station. A group of tilapia fish; $O$. niloticus, with a total length mean of $15 \pm 1 \mathrm{~cm}$, and samples of the shrimp; M. affinis, were collected during in this period.

\section{Water Physicochemical Parameters}

Water samples were brought to the laboratory of marine science center and immediately filtered using Whitman 541 filter paper. Nitric acid was used to acidify the filtered samples, then they were stored at $\left(4^{\circ} \mathrm{C}\right)$ before analysis. The investigated parameters included $\mathrm{Ca}, \mathrm{Mg}, \mathrm{Cl}, \mathrm{Fe}, \mathrm{SO} 4$, TSS and $\mathrm{PO} 4$ which were measured by using standard procedures methods (APHA 1998). Temperature $\left({ }^{\circ} \mathrm{C}\right.$ ), concentration of hydrogen ions $(\mathrm{pH})$, electrical conductivity $(\mathrm{mScm}-1)$ and total dissolved solids (TDS) were recorded by using multimedia water checker (YASI) model 556 MPS.

To indicate the nature and sources of hazardous elements, heavy metals of the total copper $(\mathrm{Cu})$, zinc $(\mathrm{Zn})$, cadmium $(\mathrm{Cd})$ and lead $(\mathrm{Pb})$ in water samples were measured after digestion process (Islam et al., 2015).The atomic absorption spectrometer type, 
Shimadzu 1800 PC, (Japan) was used to estimate the targeted heavy metals. In addition, the standard curve method was used to calculate metal concentrations.

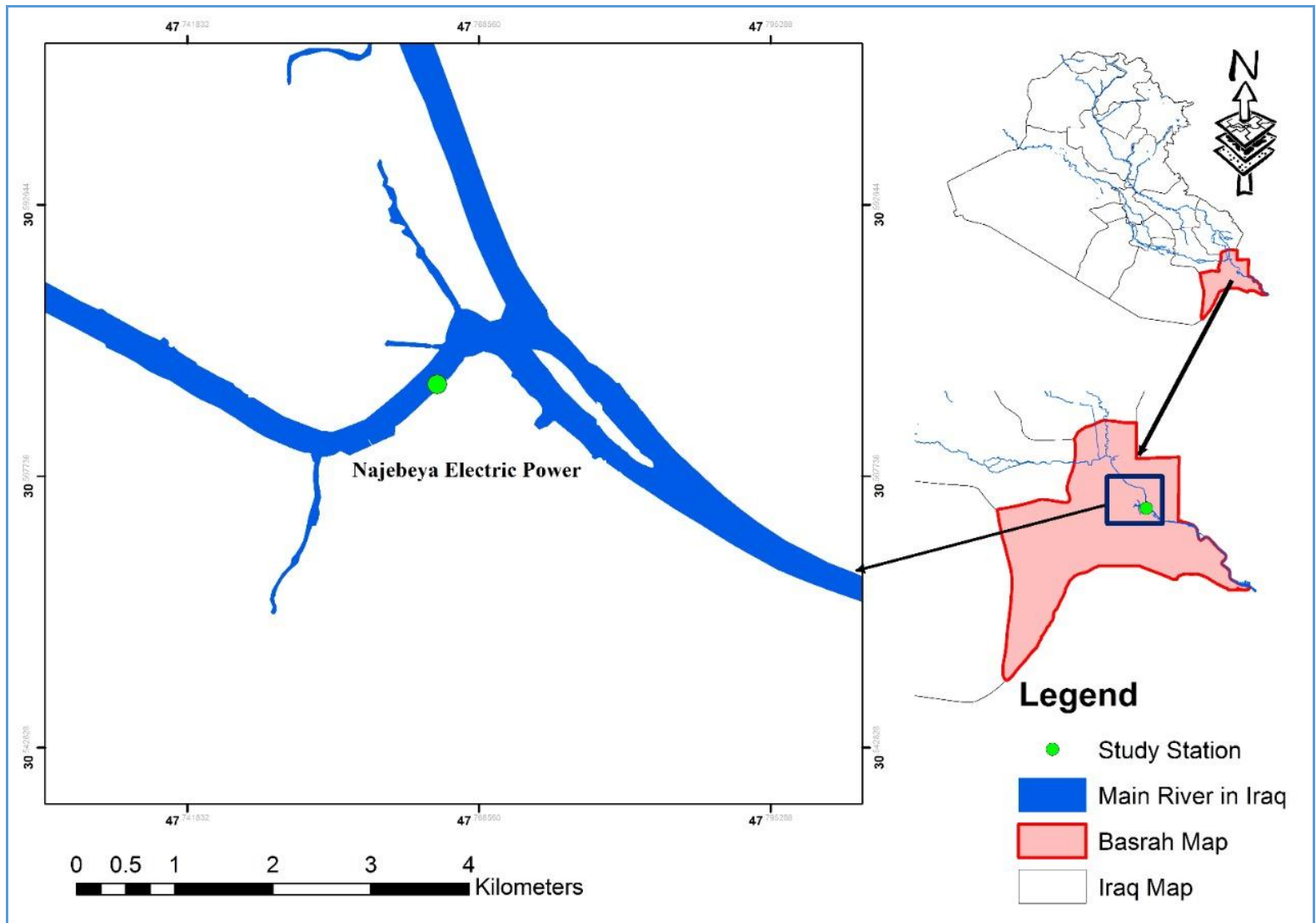

Fig. 1. Sampling sites of water, tilapia fish; Oreochromis niloticus, and shrimp; Metapenaeus affinis, in Shatt al-Arab river near Al-Najibiya electric power plant.

\subsection{Fish and shrimp samples preparation and analysis}

After defreezing fish, they were dissected with stainless steel knives then liver, gills and muscle tissues were collected for heavy metal bioaccumulation tests. Shrimp shells were removed and the whole soft tissue was analyzed. The samples were homogenized and weighed in a dry powdered form which were $1 \mathrm{~g}$ for gill, muscle and shrimp samples but the dry form weight for liver was $0.1 \mathrm{~g}$. The processes were conducted in three replicates and then digested later by using a mixture of a high-purity (65\%) nitric acid and hydrogen peroxide (35\%) with a ratio of 3: 1 (Durali et al., 2010). Blanks were simultaneously used in each batch of analysis to authenticate the analytical quality. The analysis were conducted by using the atomic absorption spectrometer type, Shimadzu 1800 PC, (Japan). The assessment of the concentrations included four metals: copper $(\mathrm{Cu})$, zinc $(\mathrm{Zn})$, cadmium $(\mathrm{Cd})$ and lead $(\mathrm{Pb})$. The standard solutions of the elements supplied by Merck Company were used for calibration after dilution of stock. The results 
were calculated in milligram per kilogram $(\mathrm{mg} / \mathrm{kg})$ dry weight. All glassware and plastics were soaked in $10 \%$ dilute nitric acid overnight, then rinsed with distilled water and deionized water, and dried before use in the analysis processes (Csuros \& Csuros, 2002).

\section{RESULTS AND DISCUSSION}

The mean of water quality parameters was measured from three water sources in this study for four seasons as shown in Figure (2) and Table (1). Results showed that conductivity values were higher than the permissible limits comparing to those of the Demi industrial water $(11728.04,11645.25$ and $182.96 \mathrm{mg} / \mathrm{l})$ for raw, chanel and demi water (Figure 2), especially in autumn, recording a value of $18586 \mathrm{mg} / \mathrm{l}$ in raw river water. This was due to the decrease of water discharge of the Tigris and Euphrates rivers, in addition to salt wedge of the Arabian Gulf during that period. The recorded values of TDS were 8702.13 and $8487.13 \mathrm{mg} / \mathrm{l}$ for raw and chanal water, respectively. Values were above the permissible limit of human and industrial uses. According to CCME (2008) the permissible limit (conductivity, TDS, and TSS) for drinking water is 1000, 500.00, --, and for industrial water uses, the permissible limit is $<7000,<5000,<5000$, respectively.

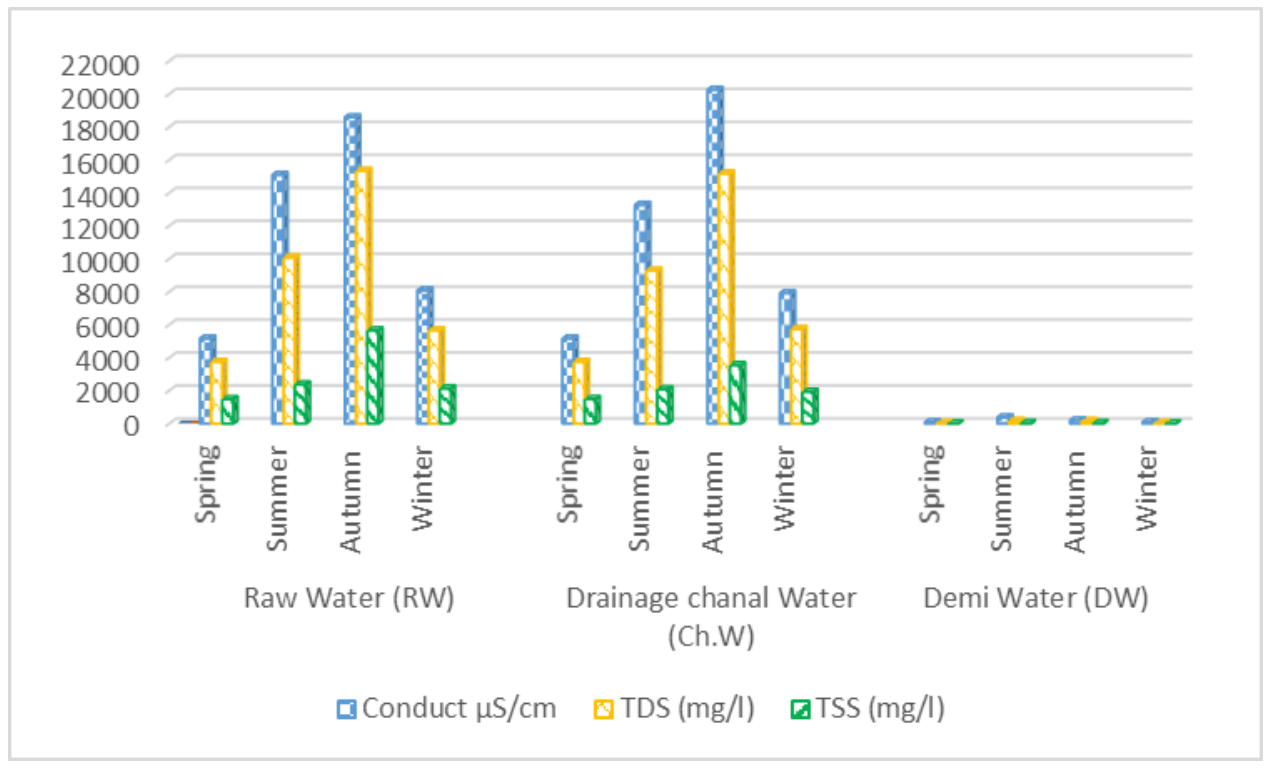

Fig. 2. Conductivity ( $\mu \mathrm{S} / \mathrm{cm})$, total dissolved solids ( $\mathrm{mg} / \mathrm{l})$, and total suspended solids $(\mathrm{mg} / \mathrm{l})$ of Shatt al-Arab river, drainage channel and demi water from Al-Najibiya electric power plant during the four seasons of Mar 2018 - Feb 2019.

The discharge of Shatt al-Arab river that varied between 243 and $273.0 \mathrm{~m} 3 / \mathrm{sec}$ as well as the conditions of the tide and the low levels of water resulted in an increase in the concentration of salinity and total dissolved substances (TDS) (Al- Mahmood, 2009). 
Consequently, the water quality would decline, and the low level of water in Shatt alArab would affect its validity for various uses, especially during summer where water discharge reaches its minimum, beside the tidal status, the water salinity and the TDS that would increase comparing to previous years. The variation of water quality of Shatt alArab river prejudiced by the marine salt wedge from Arabian Gulf and the chemical ions inflow from the Tigris river.

The data of this study indicated that TSS value were higher than the permissible levels for drinking or industrial uses. Their prevalence in power plant mean values were 2910 and $2259 \mathrm{mg} / \mathrm{l}$ for raw and chanal water, respectively while the produced demi water was within the permissible limit $(21.88 \mathrm{mg} / \mathrm{l})$. Total suspended solids (TSS) recorded high value $(5653.33 \mathrm{mg} / \mathrm{l})$ in autumn which was not suitable for industrial or drinking uses (Figure 2). Unusual high TSS concentrations results have negative effects on fish physiology and behaviour and trans generational implications (Kjelland et al., 2015). Moreover, it might have respiratory impacts via thickening gill lamellae if its concentrations reached 100-500 mg/l for a duration of 21 days (Cavanagh et al., 2014)

The current results showed that the $\mathrm{pH}$ was constant in all sample sources and all values were in alkaline (6.5-7.9) (Table 1). However, the $\mathrm{pH}$ in water from all different sources (raw, drainage and demi water) were within the acceptable levels. The aquatic life thrives in aquatic habitats in which the $\mathrm{pH}$ is near a narrow or a critical range. Furthermore, at lower $\mathrm{pH}$ values, metals tend to be more toxic because they are more soluble (Mota et al., 2018). The present findings showed that the values of water temperature ranged from $20.5-30.3{ }^{\circ} \mathrm{C}$, and the average value was within permissible levels.

A deterioration in the water quality of Shatt al-Arab was observed during the hot months, especially in the summer season, this decrease can be attributed to the major deficiency of water supplies from the Tigris and Euphrates rivers, higher evaporation rates, as well as the increase in water consumption via summer crops which were planted in lands close to water saving sources.

Many studies indicated that the water quality of Shatt al-Arab river tended to be moderate or poor leveled (Abbas \& Hassan, 2018). They assessed that water quality of Euphrates river ranged between poor to marginal, and recorded a range of TDS (679$1109 \mathrm{mg} / \mathrm{l})$ and $\mathrm{PO}_{4}(0.71-1.81 \mathrm{mg} / \mathrm{l})$. The variation in the values throughout the study period (Sep. 2015- June 2016) followed the seasonal cycle as they attributed that variation to the arid climate of that region. 
Table 1. Physical and chemical parameters of water samples collected from Shatt al-Arab river, drainage channel and demi water from Al-Najibiya electric power plant during the four seasons of Mar 2018 - Feb 2019.

\begin{tabular}{|c|c|c|c|c|c|c|c|c|}
\hline $\begin{array}{l}\text { WATER } \\
\text { SOURCE }\end{array}$ & SEASON & $\mathrm{PH}$ & $\begin{array}{c}\mathrm{CA} \\
(\mathrm{MG} / \mathrm{L})\end{array}$ & $\begin{array}{c}\text { MG } \\
(\mathrm{MG} / \mathrm{L})\end{array}$ & $\begin{array}{c}\mathrm{CL} \\
(\mathrm{MG} / \mathrm{L})\end{array}$ & $\begin{array}{c}\mathrm{SO}_{4} \\
(\mathrm{MG} / \mathrm{L})\end{array}$ & $\begin{array}{c}\mathrm{PO}_{4} \\
(\mathrm{MG} / \mathrm{L})\end{array}$ & $\begin{array}{c}\text { TEMP. } \\
{ }^{\circ} \mathrm{C}\end{array}$ \\
\hline \multirow{5}{*}{$\begin{array}{l}\text { RAW } \\
\text { WATER } \\
(\text { RW) }\end{array}$} & Spring & 7.86 & 613.00 & 573.00 & 1225.00 & 821.00 & 3.44 & 22.60 \\
\hline & Summer & 8.20 & 622.50 & 1772.50 & 4861.00 & 1173.00 & 4.15 & 29.98 \\
\hline & Autumn & 7.60 & 1426.67 & 2726.67 & 5796.67 & 1243.67 & 3.10 & 25.02 \\
\hline & Winter & 7.35 & 701.50 & 1178.00 & 1756.50 & 1665.00 & 1.35 & 21.95 \\
\hline & Mean & 7.75 & 840.92 & 1562.54 & 3409.79 & 1225.67 & 3.01 & 24.89 \\
\hline \multirow{5}{*}{$\begin{array}{l}\text { DRAINAGE } \\
\text { CHANAL } \\
\text { WATER } \\
(\text { CH.W) }\end{array}$} & Spring & 7.88 & 615.00 & 577.00 & 1236.00 & 821.00 & 3.44 & 20.50 \\
\hline & Summer & 7.98 & 490.00 & 1022.50 & 4099.00 & 1079.25 & 3.78 & 29.93 \\
\hline & Autumn & 7.57 & 1138.33 & 2410.00 & 5260.00 & 1174.83 & 2.37 & 25.13 \\
\hline & Winter & 7.52 & 1096.67 & 505.33 & 2367.67 & 1227.67 & 1.70 & 20.67 \\
\hline & Mean & 7.74 & 835.00 & 1128.71 & 3240.67 & 1075.69 & 2.82 & 24.06 \\
\hline \multirow{7}{*}{$\begin{array}{l}\text { DEMI } \\
\text { WATER } \\
\text { (DW) }\end{array}$} & Spring & 6.45 & 0.00 & 0.00 & 20.00 & 10.00 & 0.80 & 23.60 \\
\hline & Summer & 6.70 & 0.00 & 0.00 & 50.00 & 33.25 & 1.98 & 30.35 \\
\hline & Autumn & 6.30 & 0.00 & 0.00 & 48.83 & 39.50 & 1.78 & 25.27 \\
\hline & Winter & 6.45 & 0.00 & 0.00 & 20.00 & 11.00 & 0.85 & 21.50 \\
\hline & Mean & 6.48 & 0.00 & 0.00 & 34.71 & 23.44 & 1.35 & 25.18 \\
\hline & $\begin{array}{l}\text { Permissible } \\
\text { limit for } \\
\text { drinking } \\
\text { water* }\end{array}$ & $\begin{array}{r}6.5- \\
8.5\end{array}$ & 50 & 0.05 & 250.00 & 200 & 0.06 & \\
\hline & $\begin{array}{l}\text { Permissible } \\
\text { limit for } \\
\text { industrial } \\
\text { water* }\end{array}$ & $\begin{array}{l}6.5- \\
8.5\end{array}$ & $<200$ & $<0.01$ & $<600$ & $<680$ & -- & $\begin{array}{l}\text { over } \\
5^{\circ} \mathrm{C}\end{array}$ \\
\hline
\end{tabular}

The recorded values of $\mathrm{Ca}$ and $\mathrm{PO}_{4}$ concentrations (840 and $3.1 \mathrm{mg} / \mathrm{l}$ ) in raw water of river respectively (Table, 1) were higher than the permissible concentration levels. The source of these elements is mainly related to the industrial raw materials and the agricultural drainage waters (Grela et al., 2020). Liquid wastes from thermal power plants were rich in phosphates due to the use of tri sodium phosphate in boiler's feeding water as an anti-scaling agent where it reacts with dissolved solids to form materials that can be detached by blowing (Gill $\boldsymbol{e t}$ al., 1998). The highest concentrations of magnesium (1562 and $1128 \mathrm{mg} / \mathrm{l}$ ) were in raw and chanal water respectively, which was attributed to its occurrence in matters of special industrial emulsification breakers, and coming from the river water of Shatt al-Arab. 
Furthermore, sulphate average values were 1225.67 and $1075.69 \mathrm{mg} / \mathrm{l}$ for raw and chanal water, respectively, their values exceeded the standard values of CCME (2008) for drinking and industrial uses compared to the data of demi water sulphate which was within permissible level (Table 1). Markedly, high sulphate concentrations is known to have a salty and bitter taste and may have negatively effects on some individuals at high levels (Lopiz et al., 2017). On the other hand, an observation by Geurts et al. (2009) reported that $\mathrm{SO} 4$ pollution and associated sulphide products greatly reduced biomass production and colonization, additions of SO4 concentrations increased alkaline and sulfide concentrations resulting in hydrolysis and increased eutrophication.

Mean recorded values of chloride (3409.79 and $3240.67 \mathrm{mg} / \mathrm{l}$ ) for raw and chanal water correspondingly were higher than the permissible standard limit for both drinking and industrial uses (Table 1). It is worthy to consider that chloride ions causes environmental harm, especially to organisms living in water. Moreover, high chloride concentrations are toxic, carcinogenic, classified as mutagenic contaminants and can cause disorders of the endocrine glands (Granato et al., 2015). Findings showed that, the produced demi water value $(34.71 \mathrm{mg} / \mathrm{l})$ was within the permissible limits. Most of the chloride ions sources in the raw waters of the river were due to the salt wedge coming from the Arabian Gulf waters during the autumn season 2018, which contained a high quantity of $\mathrm{Cl}$ element (Lateef et al., 2020).

Al-Saadi et al. (2020) studied those parameters in Shatt al-Arab river during the period 2017 to 2018, and found that the minimum value of salinity was 916 while the highest value was $42844 \mathrm{mg} / \mathrm{l}$. The cations in surface water represented by $\mathrm{Ca}^{2+}$ and $\mathrm{Mg}^{2+}$ ranged from $78-780 \mathrm{mg} / \mathrm{l}$ and $51-1054 \mathrm{mg} / \mathrm{l}$, respectively, while PO4 was $0.22-0.97 \mathrm{mg} / \mathrm{l}$, sulphate was $140-1600 \mathrm{mg} / \mathrm{l}$ and $\mathrm{Cl}^{-}$was $225-22325 \mathrm{mg} / \mathrm{l}$. In general, the statistical analyses (one way ANOVA) of water quality in raw and chanal water varies among the four seasons, and have significant differences $(\mathrm{p}<0.05)$ between sampling seasons.

It was observed through the current study that, Shatt al-Arab river suffers from a deterioration in water quality, and this agrees with the results of Gatea (2018) about Shatt al-Arab river which showed that water quality was not suitable for drinking and could be used for agricultural purposes. In his study, the parameters recorded high values in stations to the south of Shatt al-Arab river compared to the permissible limits in which $\mathrm{Ca}, \mathrm{Mg}$, SO4, and TDS were 560, 1763, 1300, and $4727.33 \mathrm{mg} / \mathrm{l}$, respectively. The present results also coincide with the findings of the study of Ibrahim (2013) on AlDoura thermal power station, Baghdad, Iraq, staating that wastewater parameters $(\mathrm{pH}$, TSS, SO4, $\mathrm{Cl}$ and Temp.) were recorded with relatively high concentrations compared to raw water. It ranged at a lower and a higher value (7.3-8.3, 43-160, 210-450, 78- 134 $\mathrm{mg} / \mathrm{l}$ and $19-40^{\circ} \mathrm{C}$ ), respectively in winter and summer 2012 . In addition, the previous author concluded that the properties of wastewater was out of restrictions, especially those of temperature and total suspended solid (TSS). 
Tables (1 )and (2) show that the demi water produced by the power plant is valid and can be purified and recycled; to be used in industrial processes and drinking too. This finding is similar to the study of Mohsen (2004) on industrial wastewater reuse in Jordan's Al Hussein thermal power station. He found that that wastewater could be treated by filtration, including reverse osmosis, and then recirculated in the plant as process water.

A thorough analysis on the level of heavy metals parameters in chosen water regions was carried out (Table 2). Presence of heavy elements of $\mathrm{Cd}$, and $\mathrm{Pb}$ were slightly higher in collected water samples from raw river and drainage chanal water than permissible limit. The concentration of $\mathrm{Cd}$ and $\mathrm{Pb}$ were reported $(0.62$ and 0.14$)$ for raw water and (0.17 and 0.15) for drainage chanal water samples respectively. However, the concentrations of $\mathrm{Cu}$ and $\mathrm{Zn}$ metals in water from all three water sources were within the permissible levels of Canadian environmental quality (CCME 2008).

The concentrations of heavy metals in industrial waste water were the result of AlNajibiya power plant, because it runs on heavy fuel oil (HFO), which contains a lot of chemical elements including heavy metals. Industrial pollutants, like $\mathrm{Cd}, \mathrm{Cu}, \mathrm{Cr}, \mathrm{Fe}$ and $\mathrm{Ni}$, which are mainly colorless and odorless, are released into the environments and therefore, these elements have become a source of threat to aquatic organisms (Singare $\boldsymbol{e t}$ al., 2011).

Table 2. Heavy metals concentration $(\mathrm{mg} / \mathrm{l})$ of water samples collected from Shatt alArab river, drainage channel and demi water from Al-Najibiya electric power plant.

\begin{tabular}{ccccc}
\hline $\begin{array}{c}\text { Water } \\
\text { Source }\end{array}$ & $\begin{array}{c}\mathbf{C d} \\
(\mathbf{m g} / \mathbf{l})\end{array}$ & $\begin{array}{c}\mathbf{C u} \\
(\mathbf{m g} / \mathbf{l})\end{array}$ & $\begin{array}{c}\mathbf{P b} \\
(\mathbf{m g} / \mathbf{l})\end{array}$ & $\begin{array}{c}\mathbf{Z n} \\
(\mathbf{m g} / \mathbf{l})\end{array}$ \\
\hline Raw Water & 0.62 & 0.01 & 0.14 & 0.04 \\
\hline $\begin{array}{c}\text { Drainage } \\
\text { chanal } \\
\text { water }\end{array}$ & 0.17 & 0.03 & 0.15 & 0.04 \\
\hline $\begin{array}{c}\text { Demi } \\
\text { Water }\end{array}$ & 0.07 & 0.01 & 0.08 & 0.01 \\
\hline $\begin{array}{c}\text { Permissible } \\
\text { limit* }\end{array}$ & 0.005 & 1.00 & 0.05 & 5.00 \\
\hline *Canadian environmental quality guidelines.
\end{tabular}

The present study revealed that, Shatt al-Arab is impacted by industrial effluents with high organic matter untreated discharge, and affected by domestic sewage as well which could be a source of a lot of heavy metals. This result concurs with that of Aljabri et al. (2016), with respect to the concentrations of six metals including: $\mathrm{Pb}, \mathrm{Cu}$ and $\mathrm{Zn}$ in river sediments recording ranges of $11-17 \mathrm{mg} / \mathrm{l}$ for $\mathrm{Pb}, 31-40 \mathrm{mg} / \mathrm{l}$ for $\mathrm{Cu}$, and $108-$ $127 \mathrm{mg} / \mathrm{l}$ for Zn. Whereas, Al-Asadi et al. (2019) observed a uniform distribution and low concentrations of most elements in the river water which were $<5$ and $<1 \mu \mathrm{g} / \mathrm{l}$ for $\mathrm{Pb}$ 
and $\mathrm{Cd}$ respectively, they designated that the contaminated sources of river were the air deposits of gaseous releases from oil manufacture and electrical generators.

Table (3) shows that the average concentrations of metals in the studied tissues (liver, gill and muscles) of the tilapia fish recorded significant differences $(p<0.05)$ among different tissues. The liver had the highest bioaccumulation of metals, followed by gill tissue and muscles. The cadmium concentration $(0.86 \mathrm{mg} / \mathrm{kg})$ in the liver tissue was slightly higher than the permissible limits, while the muscle tissue of fish $(0.03 \mathrm{mg} / \mathrm{kg})$ was below the permissible concentration limits $(0.05 \mathrm{mg} / \mathrm{kg})$ as stated by $\mathbf{E C ~ ( 2 0 0 6 )}$.

Table 3. Heavy metals concentrations $(\mathrm{mg} / \mathrm{kg})$ in various tissues of tilapia; Oreochromis niloticus, and shrimp; Metapenaeus affinis, collected from Shatt al-Arab river near AlNajibiya electric power station

\begin{tabular}{lcccc}
\hline $\begin{array}{l}\text { Tissue } \\
\text { Sample }\end{array}$ & $\mathbf{C d}(\mathbf{m g} / \mathbf{k m})$ & $\mathbf{C u}(\mathbf{m g} / \mathbf{k m})$ & $\mathbf{P b}(\mathbf{m g} / \mathbf{k m})$ & $\begin{array}{c}\mathbf{Z n} \\
(\mathbf{m g} / \mathbf{k m})\end{array}$ \\
\hline $\begin{array}{l}\text { Tilapia } \\
\text { Muscle }\end{array}$ & 0.03 & 0.05 & 0.03 & 1.15 \\
\hline $\begin{array}{l}\text { Tilapia } \\
\text { Gills }\end{array}$ & 0.14 & 0.12 & 0.05 & 2.33 \\
\hline $\begin{array}{l}\text { Tilapia } \\
\text { Liver }\end{array}$ & 0.86 & 0.13 & 0.07 & 2.39 \\
\hline $\begin{array}{l}\text { Shrimp } \\
\text { tissue }\end{array}$ & 0.01 & 0.44 & 0.18 & 1.86 \\
\hline $\begin{array}{l}\text { Permissible } \\
\text { limit* }\end{array}$ & $\begin{array}{c}0.05 \text { for fish muscle } \\
0.5 \text { for fish liver and } \\
\text { shrimp }\end{array}$ & 3.0 & $\begin{array}{c}0.3 \text { for fish } \\
0.5 \text { for shrimp }\end{array}$ \\
\hline
\end{tabular}

*Permissible limit by EC 2006

Noticeably, the increase of cadmium concentration could be due to the higher concentration in the drainage chanal water of the electrical power station (Table 2). The current results agree with those of Low et al. (2011) in the evaluation of metals in tissues of red tilapia (Oreochromis sp.), reporting that liver have the ability to accumulate heavy metals, especially copper. They also found great variation in the levels of the elements for copper and cadmium, the liver samples being more distinct compared to the other samples. The present study revealed that the muscle tissue had the lowest level of mineral bioaccumulation compared to other tissues that may retain it through the circulatory system. This finding collaborates with that of AbdulMuhsin et al. (2016) in terms of the concentrations of metals $(\mathrm{Cd}, \mathrm{Cu}$, and $\mathrm{Pb})$ in carp fish; Cyprinus carpio, and water of the artificial lake of Baghdad city, Iraq $(0.200,0.111$, and $1.539 \mathrm{mg} / \mathrm{Kg}$ ) in the fish, and $(0.010,0.004$, and $0.818 \mathrm{mg} / \mathrm{l})$ for the water respectively. Statistically, the concentrations of cadmium and lead levels in fish were higher than the permissible limits. Similarily, the lead concentration in water was higher than the permissible limits too. Khoshnood and Khoshnood (2015) studied the effect of industrial waste water on Barbus grypus and Hypophthalmichthys molitrix from Karoon river, Iran, and found that the concentration of 
Hg metal increased considerably after industrialization, recording 18.92 and 25.49 mg.kg-

${ }^{1}$ in liver tissues of these fishes respectively. They related those extra concentrations to the increased concentration of the dissolved organic carbon and the discharge of the $\mathrm{Hg}$ released from petrochemical activities in these regions.

Many studies on heavy metal concluded that accumulation of metals varied depending on species-specific factors, beside others like; fish size, age and feeding behavior. Bawuro et al. (2018) studied different tissues of benthic fish; Clarias anguillaris, and pelagic fish; Heterotis niloticus, and Tilapia zillii, and reported that the concentrations of $\mathrm{Zn}, \mathrm{Cu}$ and $\mathrm{Pb}$ were of a high level in the liver (22.4, 29.87 and 3.5 $\mathrm{mg} / \mathrm{kg}$ ), respectively, while the gill targeted for Cd was $0.53 \mathrm{mg} / \mathrm{kg}$ in the C. anguillaris . These differences were related to the potential factors affecting mineral absorption such as geographical location and age, in addition to the species-specific factors.

Rajeshkumar and $\mathrm{Li}$ (2018) assessed the metals' $(\mathrm{Cd}, \mathrm{Cr}, \mathrm{Cu}, \mathrm{Pb})$ concentrations in fresh water fish (Pelteobagrus fluvidraco and Cyprinus carpio Linnaeus) and found that, concentrations means were higher in the dry season. This result was attributed to the rise in temperature, which in turn led to an increase in activity and metabolic rate, as well as an increase in feeding sessions and increased ventilation. Hashim $\boldsymbol{e t}$ al. (2014) studied Chitala chitala fish in Kelantan river, Malaysia and found that, the concentrations raised in the wet season $(\mathrm{Cd}$ concentration was $0.076 \mathrm{mg} / \mathrm{kg}$, and $\mathrm{Pb}$ was $0.169 \mathrm{mg} / \mathrm{km}$ ) in Osteochilus hasseltii and they were above the permissible limit values. It was the first ingredient to be distinguished by the type of toxicity. Generally, in animal systems, lead $(\mathrm{Pb})$ has been criminalized in a wide range of toxic effects and is considered a durable, ubiquitous heavy metal (Assi et al., 2016). However, the metals concentrations level in muscles tissues of the tilapia fish and soft tissue of the edible parts from the studied shrimps Table (3) were within the allowable levels for human consumption. Generally, all results were within the tolerable range recommended by the European Communities (EC, 2006).

\section{CONCLUSION}

The results of this study provide a basic information for the environmental assessment of Shatt al-Arab river. This river suffered from a deterioration in the water quality, especially in summer 2018. There were significant differences between the concentrations of the heavy metals in the investigated tissues (muscle, gill and liver) of the tilapia. The tilapia fish muscles and the edible parts of the studied shrimps in the study area had an acceptable concentrations of heavy metals for human consumption. Consequently, more investigations is needed to detect a wider range of river pollutants.

\section{REFERENCES}

Abbas, A.A., and Hassan, F. (2018). Water quality assessment of Euphrates river in Qadisiyah province (Diwaniyah river), Iraq. Iraqi Journal of Agricultural Sciences, 49(2): 152-162 
AbdulMuhsin, Z.A.; Al-Zubaidi, F. and Shafik, S. (2016). Estimate the concentrations of some Heavy Metals (cadmium, copper, nickel, lead) in carp fish, fish feed, water, sediment in artificial lake of Baghdad city. Iraqi Journal of Science, Special Issue, Part A: 46-54

Al- Mahmood, H.K. (2009). The monthly variations of discharge and effect that on total dissolve suspended salinity in Shatt Al-Arab river (South of Iraq). Iraqi Journal for Science, 50(3): 355-368(In Arabic)

Al- Asadi, S.A.; Al-Qurnawi, W.; Al Hawash, A.; Ghalib, H. and Alkhlifa, N. (2020). Water quality and impacting factors on heavy metals levels in Shatt Al- Arab River, Basra, Iraq. Applied Water Science, 10:103. https://doi.org/10.1007/s13201-02001196-1

Al- Asadi, S.A.; Al Hawash, A.; Alkhlifa, N. and Ghalib, H. (2019). Factors Affecting the Levels of Toxic Metals in the Shatt Al-Arab River, Southern Iraq. Earth Systems and Environment, 3:313-325. https://doi.org/10.1007/s41748-019-00096-y

Al-Asgah, NA.; Abdel-Warith, A.; Younis, E. and Allam, H. (2015). Haematological and biochemical parameters and tissue accumulations of cadmium in Oreochromis niloticus exposed to various concentrations of cadmium chloride. Saudi Journal of Biological Sciences, 22 (5): 543-550.

Aldogachi, M.A.; Sofian-Aziran, M.; Yusoff, I. and Ashraf, M.A., (2016). Ultrastructural effects on gill tissues induced in red tilapia Oreochromis sp. by a waterborne lead exposure. Saudi Journal of Biological Sciences, 23, 634-641. http://dx.doi.org/10.1016/j.sjbs .2015.08.004

Aldoghachi, M.A.; Al-Zaidy, F. and AlKatrani, L. (2019). Effects of sublethal zinc ions and acute crude oil exposure on serum enzymes activity of Carassius gibelio. $\mathbf{J}$ Anim Behav Biometeorol, 7:155-159. doi.org/10.31893/2318-1265jabb.v7n4p155159.

AlKatrani, L.M.; Jaafer, F. and Aldoghachi, M.A. (2018). Effect of sudden and gradual transfer of Oreochromis aureus to different water salinities on the activity of AST and ALT serum enzymes. JKAU: Mar. Sci., 28 (2): 81-88.

Al-Taei, S.A.; Abdulla, S. and Lafta, A. (2014). Longitudinal intrusion pattern of salinity in Shatt Al-Arab estuary and reasons. JKAU: Mar. Sci., 25 (2): 205-221(In Arabic). DOI:10.4197/Mar. 25-2.10

APHA (American Public Health Association) (1998). Standard method for the examination of water and waste water $-20^{\text {th }}$ edition. Washington, D C. (American Public Health Association pp 1136. 
Assi, M.A.; Hezmee, M.; Haron, A.; Mohd Sabri, M. and Rajion, M. (2016). The detrimental effects of lead on human and animal health. Veterinary World, EISSN, 9: 2231-0916. www.Veterinary world.org/Vol.9/June-2016/20.pdf

Bawuro A.A.; Voegborlo, R.B. and Adimado AA. (2018). Bioaccumulation of heavy metals in some tissues of fish in Lake Geriyo, Adamawa State, Nigeria. J Environ Public Health 2018:1854892-1854897. https://doi.org/10.1155/2018/1854892

Cavanagh, J. E.; Hogsden, K. L. and Harding, J. S. (2014). Effects of suspended sediment on freshwater fish. Greymouth 7805. Retrieved from http://www.envirolink.govt.nz/PageFiles/1301/ 1445-WCRC129Effects of suspended sediment on freshwater fish.pdf

CCME Canadian Council of Minister of the Environment, (2008). Canadian Water Quality Guidelines. https:// www .ccme .ca /files/ Resources /supporting _scientific _documents/cwqg_pn_1040.pdf

Chabuk, A.; Al-Madhlom, Q.; Al-Maliki, A.; Al-Ansari, N.; Hussain, H. and Laue, J., (2020). Water quality assessment along Tigris River (Iraq) using water quality index (WQI) and GIS software. Arab J Geosci 13, 654.

Durali, M.; Omer, F.; Mustafa, T. and Mustafa, S. (2010). Determination of tracemetals in different fish species and sediments from the River Yesilirmak in Tokat, Turkey. Food and Chemical Toxicology 48: 1383-1392.

European Communities, (2006). Commission Regulation (EC) No 1881/2006 of 19 December 2006 setting maximum levels for certain contaminants in food stuffs. Official Journal of the European Union, L364/5.

Gatea, M.H. (2018). Study of Water Quality Changes of Shatt Al-Arab River, South of Iraq. Journal of University of Babylon for Engineering Sciences, 26, (8): 228-241.

General Company of Electrical Energy /South Region, (2019). About company. https://www.moelc.gov.iq/sgpe?lang=en .

Geurts, J.J.; Sarneel, J.; Willers, B.; Roelofs, J.; Verhoeven, J. and Lamers, L. (2009). Interacting effects of sulphate pollution, sulphide toxicity and eutrophication. Environmental Pollution 157: 2072-2081. https://doi:10.1016/j.envpol.2009.02.024

Gill, J.S. (1998). The Role of Calcium Phosphate in Internal Boiler Water Treatment. In: Amjad Z. (eds) Calcium Phosphates in Biological and Industrial Systems. Springer, Boston, MA. https://doi.org/10.1007/978-1-4615-5517-9_18

Granato, G.E.; DeSimone, L.A.; Barbaro, J.R. and Jeznach, L.C. (2015). Methods for evaluating potential sources of chloride in surface waters and ground waters of 
the conterminous United States: U.S. Geological Survey Open-File Report 20151080, 89 p., http://dx.doi.org/10.3133/ofr20151080.

Grela, A.; Lach, M. and Mikula, J. (2020). An efficacy assessment of phosphate removal from drainage waters by modified reactive material. Materials, 13, 1190; doi:10.3390/ma13051190

Hashim, R.; Song, T.; Md Muslim, N. and Yen, T. (2014). Determination of heavy metal levels in fishes from the lower reach of the Kelantan river, Kelantan, Malaysia. Tropical Life Sciences Research, 25(2), 21-39

Islam, M.D.; Ahmed, Md.; Raknuzzaman, M.; Al- Mamun Md. and Islam, M. (2015). Heavy metal pollution in surface water and sediment: A preliminary assessment of an urban river in a developing country. Ecological Indicators, 48: 282-291. https://doi.org/ 10.1016/j.ecolind.2014.08.016.

Khoshnood, R.Z. and Khoshnood, R. (2015). Effect of industrial waste water on fish in Karoon River. Transylv. Rev. Syst. Ecol. Res., 17(1): 109-120. DOI: 10.1515/trser2015-0052.

Kjelland, M.E.; Woodley, C.M. and Swannack, T.M. (2015). A review of the potential effects of suspended sediment on fishes: potential dredging-related physiological, behavioral, and transgenerational implications. Environ. Syst. Decis., 35: 334-350. https://doi.org/10.1007/s10669-015-9557-2

Lateef, Z.Q.; Al-Madhhachi, A. and Sachit, D. (2020). Evaluation of Water Quality Parameters in Shatt AL-Arab, Southern Iraq, Using Spatial Analysis. Hydrology, 7(4) 79; https:// doi:10.3390 / hydrology 7040079

Lopez, P.; Rodríguez, I.; Estrany, F. and Devesa, R. (2017). Effects of sulfate and nitrate on the taste of water: a study with a trained panel. Journal of Water Supply: Research and Technology-Aqua, $66 \quad$ (8): $598-605$. https://doi.org/10.2166/aqua.2017.183

Mohammed, I.K.; Eassa, A. and Mohammed, L. (2014). The study of potential environmental risks of some industrial pollutants factors discharged from Najibia Power Plant upon Shatt Al-Arab River. Journal of Basrah Researches ((Sciences)), 40(1): 110-121.

Mohsen, M.S. (2004). Treatment and reuse of industrial effluents: case study of a thermal power plant. Desalination, 167: 75-86.

Mota, V.C.; Hop, J.; Sampaio, L.A.; Heinsbroek, L.; Verdegem, M.; Eding, Ep. and Verreth, J. (2018). The effect of low pH on physiology, stress status and growth 
performance of turbot (Psetta maxima L.) cultured in recirculating aquaculture systems. Aquac Res., 49:3456-3467 .https://doi.org/10.1111/are.13812.

Osorio, F. H.; Silva, L.; Piancini, L.; Azevedo, A.; Liebel, S.; Yamamoto, F.; Philippi, V.; Oliveira, M.; Ortolani-Machado, C.; Neto, F.; Cestari, M.; Assis, H. and Oliveira Ribeiro, C. (2013). Water quality assessment of the Tubarão River through chemical analysis and biomarkers in the Neotropical fish Geophagus brasiliensis. Environmental Science and Pollution Research 21:9145-9160. doi:10.1007/s11356-013-1512-5

Rajeshkumar, S. and Li, X. (2018). Bioaccumulation of heavy metals in fish species from the Meiliang Bay, Taihu Lake, China. Toxicology Reports, 5: 288-295. https://doi.org/10.1016/j.toxrep.2018.01.007

Salman, S.D.; Ali, M.H. and Al-Adhub, A.H. (1990). Abundance and seasonal migrations of the penaeid shrimp Metapenaeus affinis (H. Milne-Edwards) within Iraqi waters. Hydrobiologia 196: 79-90. https://doi.org/10.1007/BF00008895

Singare, P.U.; Jagtap, A. and Lokhande, R. (2011). Water pollution by discharge effluents from Gove industrial area of Maharashtra, India: dispersion of heavy metals and their toxic effects. International Journal of Global Environmental Issues, 11(1): 28-36. DOI: 10.1504/IJGENVI.2011.040249

Singh J.; Yadav P.; Pal A.K. and Mishra V. (2020). Water Pollutants: Origin and Status. In: Pooja D., Kumar P., Singh P., Patil S. (eds) Sensors in Water Pollutants Monitoring: Role of Material. Advanced Functional Materials and Sensors. Springer, Singapore. https://doi.org/10.1007/978-981-15-0671-0_2

Tana, H.; Polveri, G.; Martin, J.; Bertramac, M.; Wilesa, S.; Palacios, M.; Bywater, C.; White, C. and Wong, B. (2020). Chronic exposure to a pervasive pharmaceutical pollutant erodes among-individual phenotypic variation in a fish. Environmental Pollution 263(Pt A):114450

WWF (World Wildlife Fund), (2011). Better Management Practices for Tilapia Aquaculture: A Tool to Assist with Compliance to the International Standards for Responsible Tilapia Aquaculture. Version1.0. https://www.asc-aqua.org/wpcontent/uploads/2017 /07/ASC-Tilapia-Better- Management-Practices_v1.0.pdf 